The interrelationships among the formal, semi-formal, and informal credit demands of farm households in Vietnam

\begin{tabular}{|r|l|}
\hline Journal: & International Journal of Social Economics \\
\hline Manuscript ID & IJSE-11-2020-0734.R2 \\
\hline Manuscript Type: & Research Paper \\
\hline Keywords: & $\begin{array}{l}\text { Agricultural economies, Asia, Government policy, Microcredit, Rural } \\
\text { areas }\end{array}$ \\
\hline \multicolumn{2}{l}{} \\
\end{tabular}




\title{
The interrelationships among the formal, semi-formal, and informal credit demands of farm households in Vietnam
}

\begin{abstract}
Purpose - This study simultaneously explores the nexus among formal, semi-formal, and informal credit markets and farm households' credit demand determinants in Vietnam.

Design/methodology/approach - This study uses a multi-stage stratified random sampling process for a survey of 648 smallholder farmers in the Red River Delta, Vietnam. The trivariate probit model is used to address the interdependence of farm households' credit demands in different credit markets.
\end{abstract}

Findings - The results reveal complementary relationships among two pairs of credit markets (formal versus informal and semi-formal versus informal). There are dissimilarities among the determinants (household characteristics, household head's characteristics, credit history, and geographical factors) of farm households' credit demands in different markets, reflecting segmentation of Vietnam credit markets.

Practical implications - The study's empirical findings are important for policymakers and credit providers to enhance farm households' access to credit for agriculture and to improve the operations of the three credit markets.

Originality/value - This is the first empirical study in Vietnam and one of few in other developing countries simultaneously exploring the determinants of credit demand in and interrelationships among all three credit markets to provide more comprehensive and accurate results.

Keywords: farm household; credit demand; trivariate probit model; formal; semi-formal; informal credit

Paper type Research paper 


\section{Introduction}

Vietnam's agricultural sector has become more and more important and irreplaceable in the economy and rural development. Vietnam has successfully transformed from an underdeveloped agricultural economy into a recognized global exporter of many agricultural products such as coffee, rice, and cashews. Although the development of Vietnam's agriculture is undisputable, the sector mainly consists of small-scale producers who cannot take advantage of economies of scale and have lagged behind regional and other developing countries in labor, agricultural land, and water productivity. Therefore, fostering a larger-scale, innovative agricultural sector is an important priority of the Vietnamese government and the farming community for the long-term development of Vietnam's agriculture (Anh et al., 2020).

According to Moahid and Maharjan (2020), credit is a significant factor that accelerates agricultural development and modernization in developing countries. In Vietnam, credit enhances agricultural performance in both the short and long term (Anh et al., 2020). However, rural credit markets in developing economies, including Vietnam, are deficient, constrained, and segmented (World Bank, 2019). Failure to correctly recognize the credit demand of farmers might be a major reason for the ineffectiveness of credit programs in Vietnam and other developing countries.

Farm households were assumed to choose from three credit markets (formal, semi-formal, and informal) for their credit. They may have a credit demand in all three credit markets, no credit markets, or any combination in between. According to Chivakul and Chen (2008), farm households having credit demand in one credit market are defined as households who apply for credit in this credit market and those who are discouraged (i.e., who need credit but do not apply for a loan). A credit demand in one market does not exclude a demand in another credit market. In Vietnam, three coexisting markets provide credit to the rural sector: the formal, semi-formal, and informal credit markets (Khoi and Gan, 2017; Linh et al., 2019; Truong et al., 2020). The different credit markets have different characteristics such as loan value, interest rate, collateral, and procedures. Thus, it is 
important to identify the relationships among different credit markets to implement policies that aim to boost the integration of the credit markets to ultimately enhance the efficiency of the markets (Nissanke and Aryeetey, 1998).

Despite the coexistence of three rural credit markets in Vietnam, the literature on the determinants of rural households' credit demands in Vietnam (e.g., Barslund and Tarp, 2008; Duong and Thanh, 2015; Thu et al., 2020) mainly concentrates on one or two credit markets, which might result in biased estimates of credit demand determinants. In addition, to the best of our knowledge, there is no study that simultaneously investigates the linkages among the formal, semi-formal, and informal credit markets in Vietnam. This study extends the literature by simultaneously exploring the determinants of rural farm households' credit demands for agricultural purposes and the relationships among the three credit markets in the Red River Delta, Vietnam.

The study contributes to the literature in three ways. Firstly, this study provides more inclusive results on the linkages among the three credit markets. Secondly, this study uses the trivariate probit model to address the interdependence of farm households' credit demands in different credit markets. This study is one of few empirical studies to simultaneously explore the determinants of credit demands in the formal, semi-formal, and informal credit markets. Finally, the study's findings provide up-to-date evidence on the relationships of different credit markets and credit demand determinants in Vietnam. The study's results can be used by the policymakers and credit institutions to revise the credit policies, credit terms, or priorities to enhance credit access for farm households and improve the operations of the three credit markets.

The remainder of the paper is organized as follows. Section 2 discusses the literature on the determinants of farm households' credit demands and the relationships among different credit markets. Section 3 presents the data and methodology used in this study. Section 4 provides the results and discussion. Section 5 presents the main findings, policy implications, research limitations, and suggestions for future studies. 


\section{Literature review}

\subsection{Relationships among different credit markets}

In many developing countries, including Vietnam, the formal, semi-formal, and informal credit markets coexist (Linh et al., 2019; Truong et al., 2020). Formal credit providers in Vietnam are regulated and supervised by the State Bank of Vietnam (central bank), and their credit activities are pursuant to the credit institution law. The source of formal credit refers to commercial banks, policy banks, cooperative banks, people's credit funds, and licensed microfinance institutions (MFIs) (Khoi and Gan, 2017; Truong et al., 2020). Semi-formal credit providers do not operate under the credit institution law, including non-governmental organizations, unlicensed MFIs, and microfinance programs within mass organizations (e.g., Farmers' Union or Women's Union) or development projects (Truong et al., 2020). Informal credit sector includes credit providers who are unlicensed and provide credit that is not regulated by the state but relies on social sanctions or personal relationships as means of enforcement. The informal credit sources include moneylenders, relatives and friends, rotating savings and credit associations, pawnshops, and input suppliers (Linh et al., 2019; Dang et al., 2019).

The linkages among different financial markets could be conceptually classified as direct and indirect links (Nissanke and Aryeetey, 1998). The direct links can be divided into the linkages in the allocation of credit and the linkages in the mobilization of deposits. Indirect links work through the credit demand relations and could be substitute or complement in nature. If two credit markets are substitutes, the growth of one market leads to a reduction in the other. If the two credit sectors are complementary, the growth of both sectors may occur concurrently.

Given the relative importance of the indirect links, previous literature mainly focuses on the substitution or the complement among different credit markets. In fact, the results on this issue vary among different studies. Nissanke and Aryeetey (1998) provide evidence of low substitutability between formal and informal credit in countries located in the Sub-Saharan area of Africa in the 
early 1990s. The authors explain the dissimilarities in the interest rates, size, and maturities of loans in different credit markets result in a negligible amount of informal loan contracts that are comparable to the formal credit market. In contrast, Awunyo-Vitor and Abankwah (2012) find that an increasing demand for formal loans by maize farmers in the Brong Ahafo and Ashanti areas (Ghana) does not lower their demand for informal loans. The authors show that the informal and formal credit sectors are complementary rather than substitutable.

In Vietnam, Saint-Macary and Zeller (2012) examine the relationship between formal and informal credit sectors in Yen Chau (Northern Vietnam's mountainous district). Based on the survey of 300 farm households between 2007 and 2008, the authors find that informal and formal credit are imperfect substitutes. By contrast, Thu et al. (2020), who surveyed 402 poor rural households in Thai Nguyen province, Vietnam, conclude that the informal credit market has a complementary relationship and is an incentive to develop the formal credit market.

\subsection{Determinants of farm households' credit demand}

Based on the literature, the factors affecting farm households' credit demand can be classified into four groups: household characteristics, household head's characteristics, credit history, and geographical factors. However, the results on the determinants of credit demand among different studies are inconsistent regarding credit sources, survey periods, and regions (Barslund and Tarp, 2008; Dang et al., 2019).

\subsubsection{Household characteristics}

Family size: Chaudhuri and Cherical (2012) and Tran et al. (2016) assume that larger households tend to have lower capital available for production because of higher expenditure for consumption hence depend on credit. Chaudhuri and Cherical (2012) suggest that family size significantly raises the likelihood of households applying for formal credit, whereas Mpuga (2010) and Chandio et al. (2020) report no significant impact of family size. 
Household assets: Barslund and Tarp (2008) find a significant, positive relationship between household assets and formal credit demand. For semi-formal and informal credit markets, Cheng and Ahmed (2014) show that households are more likely to apply for credit with an increase in household assets' value. Duong and Thanh (2015) conclude that rural households with higher house value have a greater probability of participating in microcredit programs. However, Barslund and Tarp (2008) demonstrate more total assets decrease the possibility of demanding informal credit.

Farmland size: the more farmland, the more likely farm households demand credit to purchase important agricultural inputs such as fertilizer or improved seeds (Moahid and Maharjan, 2020). Barslund and Tarp (2008) and Cheng and Ahmed (2014) find that households with more land tend to apply for formal and semi-formal credit. However, Rizwan et al. (2019) show a negative farm size credit demand nexus and explain that farm households having less farmland might have low income and low savings, thus requiring more credit to purchase agricultural equipment and inputs.

Social status: the household head's position in the community (Pham and Izumida, 2002) is an indicator of a household's social capital. Social capital has an important role in fostering information and the exchange of ideas, decreasing information asymmetry to reduce transaction costs, and enhancing cooperation and the reputation of individuals (Sanchez-Famoso et al., 2013). Li et al. (2020) assume that a household head who is a member of the government might raise the confidence of a household about obtaining credit, which positively affects the likelihood of applying for credit. Li et al.'s (2020) results show that households with the head as a member of the government are more likely to apply for a loan.

Social group participation: social group participation may encourage farmers to exchange ideas related to alternative sources of finance, new investment projects, etc., and hence create an increased need for credit (Reyes, 2011). Akudugu (2012) examines the factors that influence farmers' demand for credit supplied by rural banks in Ghana. The author finds that participating in a farm-based group is likely to increase farmers' agricultural credit demands. Djoumessi et al. (2018) 
confirm that agricultural association participation significantly, positively affects credit demand and credit access by smallholder farmers.

Livestock production: Pham and Izumida (2002) find that livestock production has a significant, positive influence on households' probability of borrowing from the Vietnam formal credit market. The authors explain that livestock production generates a relatively higher rate of return. Thus, rural farm households in Vietnam are more likely to borrow to invest in livestock production. However, Moahid and Maharjan (2020) conclude that livestock ownership has an insignificant impact on farm households' likelihood of participating in the formal and informal credit markets in rural Afghanistan.

\subsubsection{Household head's characteristics}

Gender: Previous studies reveal males are more likely to have a high demand for formal loans (Zeller, 1994; Chaudhuri and Cherical, 2012). Mpuga (2010) concludes men exhibit a higher level of credit demand from formal, semi-formal, and informal sources than women since men experience a greater chance of accessing production resources. In contrast, Dang et al. (2019) reveal women are positively related to the adoption of both formal and informal credit in Lam Dong province, Vietnam. Chandio et al. (2020) show the gender of the rural household head does not significantly affect a household's formal credit demand.

Age: The literature reveals mixed results of the impact of household head's age on credit demand. Cheng and Ahmed (2014) and Lin et al. (2019) find a significant, negative influence of the household head's age on the likelihood of applying for credit. According to Cheng and Ahmed (2014), the elderly in rural areas often have little formal education and have fewer productive investment projects, leading to low credit demand. Zeller (1994) and Mpuga (2010) show the opposite results.

Educational level: Empirical results from Mpuga's (2010) and Rizwan et al.'s (2019) studies show a significant, positive impact of household head's education level on formal and informal credit demands. Barslund and Tarp (2008) and Lin et al. (2019) demonstrate the opposite for the informal credit market, i.e., demand for informal credit is likely to decrease with increased years of formal 
education. One possible explanation is that a better-educated household head is likely to have better access to formal credit.

Farming experience: The theoretical expectation of the effect of farming experience on credit demand is unclear. Farmers with more years in farming might have new ideas to improve productivity and need capital to realize these ideas, resulting in increased credit demand. On the other hand, farm households with more farming experience are likely to achieve greater efficiency, which generates more capacity for self-financing (Reyes, 2011). The literature shows mixed results on farming experience's influence on credit demand. Chandio et al. (2020) confirm that an increase in farming years is likely to increase a farmer's demand for credit. However, Atieno (1997) demonstrates farming experience significantly, negatively influences credit demand.

\subsubsection{Credit history related factors}

Previous studies have examined the effect of credit history variables, including bad credit history (Barslund and Tarp, 2008), granted credit in the past years (Jia et al., 2010), outstanding loans (Das and Laha, 2017), on a farm household's credit demands. Barslund and Tarp (2008) conclude that a bad credit history positively, significantly affects rural households' demand for informal credit but does not influence the demand for formal credit. The authors explain that a bad credit history makes it difficult for rural households to secure formal loans. Thus, they turn to informal credit providers for their credit needs. Jia et al. (2010) reveal that having formal credit in the past three years has an insignificant effect on households' willingness to borrow from formal credit sources. Das and Laha (2017) show that having outstanding formal credit does not significantly affect a household's probability of applying for new formal credit.

\subsubsection{Geographical factors}

The geographical factors that may affect a farm household's credit demands are distance to credit sources and regional differences. Chandio et al. (2020) discover that a long distance to financial institutions or credit providers has a significant, negative influence on rural households' likelihood of 
applying for credit since the long distance increases transport costs for the loans. In contrast, Svotwa et al. (2020) conclude that farm household - bank distance is not significantly related to credit demands. For regional differences, Barslund and Tarp (2008) use dummy variables to distinguish provincial differences in Vietnam and find regional differences significantly impact the households' credit demands.

\section{Data and methodology}

\subsection{Data}

This study surveyed Vietnamese smallholder farm households whose main income was from crops and livestock production because $70 \%$ of the gross output of Vietnam's agricultural sector is from crops and livestock, and most Vietnamese agricultural producers are smallholder households (World Bank, 2019). The survey was conducted from April to July 2020 in the Red River Delta (RRD). The RRD was chosen for two reasons: (1) the region contributes $14 \%$ of the national agricultural gross valueadded (NAGVA) and is among the three largest agricultural production areas in Vietnam; and (2) the region experiences serious land segmentation and small-scale agricultural landholdings that may limit farm households' access to credit (World Bank, 2019).

This study uses a multi-stage stratified random sampling process for the survey. First, the relevant provinces in the region were categorized into three groups according to income (high, middle, and low). Next, Ha Noi, Hai Duong, and Ha Nam provinces were randomly chosen to represent the high, middle, and low income groups, respectively. In each province, two random rural districts were selected (Phuc Tho and Ba Vi districts in Ha Noi; Binh Luc and Thanh Liem districts in Ha Nam; and Kinh Mon and Binh Giang districts in Hai Duong). Finally, a random commune that had crops and livestock production was identified in each of the six districts. Overall, 750 farm households took part in the survey (125 farm households in each commune), resulting in 648 valid questionnaires (86.4\%) for empirical analysis. 


\subsection{Trivariate probit model}

Apart from observable factors, there are unobserved factors that could simultaneously influence farm households' credit demands in different credit markets. For example, farm households may have dissimilar judgments on the "pros and cons" of one credit market compared with the other options because of their understanding of the loan products or the requirements of the different credit markets. Thus, the decision to have a credit demand in each credit market may not be independently based on farm households' judgments. This could lead to the correlation of farm households' propensity of having credit demand in different credit markets. The correlation between credit demands in different credit markets implies either a substitutable (negative correlation) or complementary relationship (positive correlation). Failure to capture unobserved factors and the nexus among agricultural credit demands in different credit markets will lead to bias and inefficient estimates. Therefore, this study uses the trivariate probit model (TVPM) to explore the determinants of farm households' credit demands. The TVPM allows the determinants of credit demand in three different credit markets to be investigated jointly. In addition, TVPM can deal with the interdependence (pairwise correlations) between credit demands in any pair of different credit markets (Triguero et al., 2013). The coefficients of these pairwise correlations can be used to test the complement/ substitution relationships among the three credit markets. The specifications of the TVPM can be expressed as:

$$
\begin{aligned}
& D C_{k i}^{*}=\theta_{k}{ }^{\prime} Z_{k i}+\varepsilon_{k i}, k \in\{1,2,3\} \\
& D C_{k i}=1 \text { if } D C_{k i}^{*} \geq 0 \text { and } 0 \text { otherwise }
\end{aligned}
$$

where: $k=1,2,3$ denote formal, semi-formal, and informal credit markets, respectively; $D C_{k i}^{*}$ is a latent variable capturing the unobserved propensity of farm household $i$ to have a credit demand in credit market $k ; D C_{k i}$ is a binary variable indicating farm household $i$ 's observed credit demand in credit market $k$ ( 1 if farm household demands credit in credit market $k$ and 0 otherwise); $Z_{k i}$ is a vector of explanatory variables (see Table 1 ); $\theta_{k}$ is the corresponding parameter vector; and $\varepsilon_{k i}$ is 
error term capturing the influence of unobserved factors on farm households' credit demands. $\varepsilon_{k i}$ (for $k=1,2,3$ ) jointly follows a trivariate normal distribution (Ramful and Zhao, 2008):

$$
\left(\varepsilon_{1 i}, \varepsilon_{2 i}, \varepsilon_{3 i}\right)^{\prime} \sim \operatorname{TVN}\left(0,\left[\begin{array}{ccc}
1 & \rho_{12} & \rho_{13} \\
\rho_{12} & 1 & \rho_{23} \\
\rho_{13} & \rho_{23} & 1
\end{array}\right]\right)
$$

The off-diagonal elements, $\rho_{l m}$ (for $I, m=1,2,3 ; I \neq m$, and $\left.\rho_{l m}=\rho_{m l}\right)$, indicate the correlation coefficient of $\varepsilon_{l}$ and $\varepsilon_{m} . \rho_{l m}$ captures the unobserved correlations among the error terms of different credit demand latent equations.

The trivariate joint probabilities can be expressed as (Blind and Müller, 2019):

$$
\begin{aligned}
& \operatorname{Prob}\left(D C_{1}=d c_{1 i}, D C_{2}=d c_{2 i}, D C_{3}=d c_{3 i} \mid z_{1}, Z_{2}, Z_{3}\right)=\Phi_{3} \\
& \left(q_{1 i} \theta_{1}^{\prime} Z_{1 i}, q_{2 i} \theta_{2}^{\prime} Z_{2 i}, q_{3 i} \theta_{3}{ }^{\prime} Z_{3 i} ; q_{1 i} q_{2 i} \rho_{12}, q_{1 i} q_{3 i} \rho_{13}, q_{2 i} q_{3 i} \rho_{23}\right)
\end{aligned}
$$

where: $d c_{k i}=1$ if farm household $i$ has a credit demand in credit market $k$ and 0 otherwise $(k=1,2,3)$; $q_{k i}=2 d c_{k i}-1 ; \Phi_{3}($.$) denotes the standard trivariate normal distribution's cumulative distribution$ function.

The model's log-likelihood function (Blind and Müller, 2019) is expressed as:

$$
\log L=\sum_{1}^{N} \log \Phi_{3}\left(q_{1 i} \theta_{1}{ }^{\prime} Z_{1 i}, q_{2 i} \theta_{2}{ }^{\prime} Z_{2 i}, q_{3 i} \theta_{3}{ }^{\prime} Z_{3 i} ; R\right)
$$

where: $\mathrm{N}$ is the number of observations; the covariance matrix $\mathrm{R}$ of errors has the off-diagonal elements $R_{l m}=q_{l i} q_{m i} \rho_{l m}(($ for $l, m=1,2,3$; and $l \neq m)$.

Following Cappellari and Jenkins (2003), the Geweke-Hajivassiliou-Keane (GHK) simulator is used to estimate the trivariate probit model. Train (2009) argues that the GHK simulator is the most reliable approach to simulate normal probabilities and yields unbiased results with any given random draw number. Cappellari and Jenkins (2003) suggest that the GHK simulator produces consistent estimates when the number of draws is equal to or higher than the square root of the observed number. With a sample size of 648 , this study set the number of draws to 50 , which is well above the square root of the number of observations. 


\section{Results and discussion}

\subsection{Descriptive statistics}

Table 2 summarizes the credit demands of the surveyed farm households in the formal, semi-formal, and informal credit markets. Most (52.93\%) farm households have a credit demand (in one, two, or all three credit markets). Table 3 reports the statistics of the model's explanatory variables for the whole sample and each credit demand group. According to Table 3, households with a credit demand tend to have a smaller house and durable property value than the whole sample. The average family size, social status, socio-economic group participation, and main farm production vary among the different credit demand groups.

Regarding the household head's characteristics, formal and informal credit-demand households have a higher percentage of men than the whole sample, whereas households with semi-formal credit demand have women head more than the whole sample. These statistics indicate the different roles of men and women in demanding different types of credit. The average age of household heads with credit demand in all three credit markets is higher than for the whole sample, implying a positive relationship between the heads' age and households' credit demands. In contrast, the farming experience of household heads in the three credit markets is lower than for the whole sample, suggesting an adverse effect of farming experience on credit demand.

The mean value of a bad credit history in all three credit markets is greater than for the full sample. Thus, households with a poor credit history are inclined to have higher credit demands. Table 3 shows that the longer it takes to get to the formal and semi-formal credit sources, the higher the level of credit demand by the household.

\subsection{Empirical results}

\subsubsection{The different credit market relationships}

Table 4 shows the pairwise correlation coefficients between households' different credit demands. The coefficient $\rho_{13}$ is positive and statistically significant at $1 \%$, confirming the complementary 
relationship between the formal and informal markets. The result is consistent with the conclusions of Awunyo-Vitor and Abankwah (2012) and Thu et al. (2020) that the informal credit market has a complementary nexus with the formal credit market. Similarly, the positive, significant correlation between households' probability of demanding semi-formal and informal credit indicates informal credit and semi-formal credit are complementary. However, the value of $\rho_{23}(0.212)$ is much lower than $\rho_{13}(0.7)$, indicating that the relationship between informal and semi-formal credit is weaker than that between formal and informal credit. The coefficient $\rho_{12}$ is positive (with small value) and not statistically significant, implying that the complementary relationship between formal and semiformal credit is unclear. This might be because of the differences in the target client groups of each credit market, small value of semi-formal loans, and the limited outreach of semi-formal providers (Tran, 2014).

\subsubsection{Determinants of agricultural credit demand results}

Table 5 displays the marginal effects of the explanatory variables on farm households' credit demands. According to Triguero et al. (2014), the coefficients of TVPM indicate the impact of explanatory variables on the latent variable (i.e., the household's propensity to have a credit demand), whereas the marginal effects report the impact of the explanatory variables on the possibility of a positive outcome (i.e., household has a credit demand in one market). Thus, the marginal effects are presented in Table 5 rather than coefficients of TVPM to better measure the explanatory variables' influence on households' probability of having a credit demand. The variance inflation factor (VIF) test results show that the mean VIF and each explanatory variable's VIF are less than 10, confirming that the TVPM does not suffer from multicollinearity (VIF results are provided upon request).

Table 5 shows that the Wald test $\left(\chi^{2}(54)=185.56\right)$ is significant at $1 \%$, suggesting the overall significance of the TVPM. The independence test for households' credit demand in different credit 
markets $\left(\rho_{12}=\rho_{13}=\rho_{23}=0\right)$ is significant at $1 \%$, confirming the joint significance of the error correlations. This result suggests that using TVPM is more suitable than univariate probit models.

Regarding household characteristics, household assets (value of house and durable property), in general, are negatively related to a farm household's credit demand for all three credit markets, implying that farm households with fewer assets are more likely to rely on credit for agricultural purposes. This is consistent with Barslund and Tarp's (2008) result for informal credit demand but contrary to the results in Barslund and Tarp (2008) and Mpuga (2010) for formal credit demand, and Cheng and Ahmed (2014) for semi-formal and informal credit demand. A possible explanation is that households with fewer assets might face economic pressures that lead to a higher demand for credit to invest in new agricultural projects to achieve a higher income and accumulate more assets.

Farm size positively affects a farm household's probability of having a formal credit demand. Holding other variables constant, a farm household with over a $1000 \mathrm{~m}^{2}$ farmland size is $2 \%$ more likely to have a formal credit demand. This might be explained by the fact that credit from formal providers is primarily used for production (Linh et al., 2019). This supports Barslund and Tarp's (2008) and Cheng and Ahmed's (2014) conclusions that farm size has a positive influence on formal credit demand.

For the household head's characteristics, the head's gender has different effects on the household's credit demands in the different credit markets. Table 4 shows that male-headed households are $8.8 \%$ more likely to have formal credit demand than female-headed households. This result supports the findings of Zeller (1994) and Chaudhuri and Cherical (2012). On the other hand, male-headed households are $5.6 \%$ less likely to have semi-formal credit demand than female-headed households. The possible explanation is that the semi-formal credit sector attempts to supply financial services to specific groups of the population that are excluded from formal financial services, such as the poor and women (Tra and Lensink, 2008; Khoi and Gan, 2017). According to Le (2011), semi-formal credit providers better serve the poor and women than their formal counterparts. 
The household head's age positively affects the household's probability of having semi-formal and informal credit demands. Households whose head is over 45 years are $5.4 \%$ and $7.1 \%$ more likely to have semi-formal and informal credit demand, respectively. This supports Lin et al.'s (2019) conclusion that the head's age has a positive effect on informal credit demand. Middle-aged and elderly people in rural areas might have little formal education and have more difficulties in applying the formal lenders' complicated loan process than the younger people. Thus, older farmers might prefer semi-formal and informal credit to formal credit, suggesting segmentation of the credit markets.

The farming experience of the household head has a negative influence on the semi-formal and informal credit demand of farm households. Holding other variables constant, farm households with one more year of farming activity are $0.6 \%$ and $0.4 \%$ less likely to demand semi-formal and informal credit, respectively. This supports Atieno's (1997) study which shows a significant, negative relationship between credit demand and farming experience among Kenya's farm households. This result can be explained by the experienced farmers' capability to predict the demand for seasonal capital or input price variation, which enables them to reduce their reliance on external finance and decrease credit demand (Reyes, 2011).

For credit history-related factors, having a bad credit history significantly, positively affects farm households' probability of credit demand in all three credit markets. Households with a bad credit history in all three credit markets are $28.1 \%, 19.7 \%$, and $21.5 \%$ more likely to have formal, semiformal, and informal credit demand, respectively. A bad credit history indicates that a farm household has difficulty in repaying their loans. Thus, they might have credit demand for new agricultural projects with the expectation of gaining more income from new projects to repay bad loans.

Geographically, farm households in Hai Duong province are $13.9 \%$ and $6.2 \%$ less likely to demand formal and semi-formal credit, respectively, than those in Ha Nam province (base group). This result 
indicates that there are regional differences regarding farm households' credit demands. The result is consistent with Barslund and Tarp (2008) who show a significant influence of regional differences on rural households' credit demands. Interestingly, travelling time to the nearest semi-formal credit source significantly, positively affects households' probability of demand for formal and informal credit. Time to travel to the closest semi-formal credit source might indicate the availability of semiformal credit and the transport costs (especially when farmers need to travel multiple times to complete the loan applications). Holding other variables constant, one minute increase in travelling time to the nearest semi-formal credit source increases a household's likelihood of having a demand for formal and informal credit by $0.5 \%$. This implies that if the cost of borrowing from the semiformal credit market increases, farm households may consider more formal or informal credit.

\section{Conclusions and policy implications}

\subsection{Conclusions}

Using primary, cross-sectional data gathered from smallholder farmers in the RRD, Vietnam, this study simultaneously explores the nexus among formal, semi-formal, and informal credit markets, and credit demand determinants. The joint significance of the correlations among credit demand in different credit markets is confirmed, supporting the use of the trivariate probit model. The results show the complementary relationships between two pairs of credit markets: formal versus informal and semi-formal versus informal. The relationship between the formal and semi-formal credit markets is positive but not statistically significant. Besides, there are dissimilarities among the determinants (household characteristics, household head's characteristics, credit history, and geographical factors) of farm households' credit demands in different markets, reflecting segmentation of Vietnam credit markets.

\subsection{Policy implications}

In Vietnam, the informal credit market is still underdeveloped and remains largely neglected by policymakers. However, this study shows the complementary relationships between informal and 
formal credit markets as well as between informal and semi-formal credit markets. These results indicate that the growth of the informal market does not hinder the development of the formal and semi-formal credit markets. Therefore, the government should reassess the importance of the informal credit providers and launch new policies to integrate the informal sector with semi-formal and formal sectors to form a more efficient and cohesive rural credit market rather than trying to shrink the informal sector (Khoi et al., 2013; Tran et al., 2016). Besides, the government should support the establishment of legal advisory organizations at the village level to help farmers to prepare loan contracts with informal lenders, ensuring compliance with legal regulations and minimizing risks to both farmers and lenders.

The relationship between the semi-formal and formal credit markets is not statistically significant, reflecting the fragmentation and lack of interaction between these markets. Therefore, the government should focus on policies to expand the outreach of semi-formal lenders and provide training programs for rural households to understand the differences in loan procedures, interest rates, and collateral requirements between the formal and semi-formal credit markets.

Results from the TVPM show that disadvantaged farm households (such as households with fewer assets) are more likely to have credit demand. However, these households often lack access to credit because of the low value of the collateral (Linh et al., 2019). Thus, the government should revise the policies to create incentives and reduce the risks for formal credit institutions when granting uncollateralized credit, such as exempting corporate income tax for these loans and offering a local government guarantee to replace farm households' physical collateral. Besides, formal credit institutions should focus more on providing collateral-free credit to the joint liability group of farmers with clear-specified joint liability for group members.

Female-headed farm households are more likely to demand semi-formal credit, indicating that the semi-formal credit sector supports the formal credit sector to increase credit accessibility for disadvantaged groups of borrowers (such as women). However, the semi-formal credit market is still 
small with limited coverage (Truong et al., 2020). This issue originates from both policy-related aspects (e.g., not able to access commercial funding) and the semi-formal credit providers themselves (limited human resources, technology, poor governance, etc.) (Bui, 2017). Thus, it is important for the government to revise and amend related policies to create a more favorable environment for the development of the semi-formal credit market. In addition, the government should provide management and technology training programs for semi-formal credit providers to enhance their management and governance practices.

Farm households with a bad credit history have a higher probability of demanding credit. A bad credit history indicates the poor repayment reputation of farm households, and lenders might be reluctant to grant these households credit despite how good their agricultural projects might be. Thus, these households' access to credit is more restricted. To deal with this issue, the government should focus on improving the insurance market for agricultural production to reduce the risks for both farm households and credit providers. Additionally, credit providers should be encouraged to pay more attention to and carefully analyze new agricultural projects of farm households with a bad credit history rather than heavily rely on their reputation.

\subsection{Research limitations and future studies}

The study only investigates the determinants of one aspect of credit demand (i.e., whether farm households need credit for agricultural purposes or not) and does not examine the factors affecting the amount of credit demand. Besides, the interrelationships of credit demand among different credit markets and credit demand determinants may vary across different farming regions. Therefore, future studies should include the investigation of determinants of credit demand amount and expand the research areas outside the RRD region for a better understanding of farm households' credit demand in Vietnam. 


\section{References}

Akudugu, M.A. (2012), "Estimation of the determinants of credit demand by farmers and supply by rural banks in Ghana's Upper East Region", Asian Journal of Agriculture and Rural Development, Vol. 2 No. 2, pp. 189-200.

Anh, N.T., Gan, C. and Anh, D.L.T. (2020), "Does credit boost agricultural performance? Evidence from Vietnam", International Journal of Social Economics, Vol. 47 No. 9, pp. 1203-1221, doi: 10.1108/IJSE-04-2020-0238.

Atieno, R. (1997), "Determinants of credit demand by smallholder farmers in Kenya: an empirical analysis", Journal of Agriculture in the Tropics and Subtropics, Vol. 98 No. 1, pp. 63-71.

Awunyo-Vitor, D. and Abankwah, V. (2012), "Substitutes or Complements? Formal and Informal Credit Demand by Maize Farmers in Ashanti and Brong Ahafo Regions of Ghana", International Journal of Agriculture and Forestry, Vol. 2 No. 3, pp. 105-112, doi: 10.5923/j.ijaf.20120203.05.

Barslund, M. and Tarp, F. (2008), "Formal and informal rural credit in four provinces of Vietnam", Journal of Development Studies, Vol. 44 No. 4, pp. 485-503, doi: 10.1080/00220380801980798.

Blind, K. and Müller, J. A. (2019), "The role of standards in the policy debate on the EU-US trade agreement. Journal of Policy Modeling, Vol. 341 No. 1, pp. 21-38, doi:

10.1016/j.jpolmod.2018.09.006

Bui, T.T. (2017), "Factors affecting microfinance development in Vietnam (Doctoral dissertation, Paris 13 University, Paris, France)", available at: https://tel.archives-ouvertes.fr/tel02302637/document (accessed 20 October 2020).

Cappellari, L. and Jenkins, S.P. (2003), "Multivariate probit regression using simulated maximum likelihood", The Stata Journal, Vol. 3 No. 3, pp. 278-294, doi: 10.1177/1536867×0300300305.

Chandio, A.A., Jiang, Y., Rehman, A., Twumasi, M.A., Pathan, A.G. and Mohsin, M. (2020), "Determinants of demand for credit by smallholder farmers': a farm level analysis based on survey in Sindh, Pakistan", Journal of Asian Business and Economic Studies, ahead-of-print, doi: 10.1108/jabes-01-2020-0004.

Chaudhuri, K. and Cherical, M.M. (2012), "Credit rationing in rural credit markets of India", Applied Economics, Vol. 44 No. 7, pp. 803-812, doi:10.1080/00036846.2010.524627. 
Cheng, E. and Ahmed, A.D. (2014), "The demand for credit, credit rationing and the role of microfinance", China Agricultural Economic Review, Vol. 6 No. 2, pp. 295-315, doi: 10.1108/caer07-2012-0076.

Chivakul, M., and Chen, K. (2008), "What drives household borrowing and credit constraints? Evidence from Bosnia \& Herzegovina", working paper, IMF, Washington, DC.

Dang, H.D., Dam, A.H.T., Pham, T.T. and Nguyen, T.M.T. (2019), "Determinants of credit demand of farmers in Lam Dong, Vietnam: A comparison of machine learning and multinomial logit", Agricultural Finance Review, Vol. 80 No. 2, pp. 255-274, doi: 10.1108/AFR-06-2019-0061.

Das, A. and Laha, A. (2017), "Extent of credit rationing and its determinants: Micro-empirical evidence from rural West Bengal, India", South Asian Journal of Management, Vol. 24 No. 1, pp. 98-113.

Djoumessi, Y.F., Kamdem, C.B., Afari-sefa, V., Bidogeza, J. (2018), "Determinants of smallholder vegetable farmers credit access and demand in southwest region, Cameroon", Economics Bulletin, Vol. 38 No. 2, pp. 1231-1240.

Duong, P.B. and Thanh, P.T. (2015), "Impact evaluation of microcredit on welfare of the Vietnamese rural households", Asian Social Science, Vol. 11 No. 2, pp. 190-201.

Jia, X., Heidhues, F. and Zeller, M. (2010), "Credit rationing of rural households in China", Agricultural Finance Review, Vol. 70 No. 1, pp. 37-54, doi: 10.1108/00021461011042620.

Khoi, P. and Gan, C. (2017), "Rural Credit Market and Microfinance in Vietnam", in Microfinance in Asia (pp. 23-46), Singapore: World Scientific Publishing.

Khoi, P. D., Gan, C., Nartea, G.V. and Cohen, D.A. (2013), "Formal and informal rural credit in the mekong river delta of Vietnam: interaction and accessibility", Journal of Asian Economics, Vol. 26, pp. 1-13, doi: 10.1016/j.asieco.2013.02.003.

Le, T.T. (2011), "Vietnam rural financial market: Fact diagnostics and the policy implications for rural development of Vietnam", Journal of Economics and Development, Vol. 13 No. 1, pp. 57-73.

Li, L., Hermes, N. and Lensink, R. (2020), "Political connections and household access to bank loans: evidence from China", Economic Research-Ekonomska Istraživanja, Vol. 33 No. 1, pp. 288309, doi: 10.1080/1331677x.2019.1656099. 
Lin, L., Wang, W., Gan, C. and Nguyen, Q.T. (2019), "Credit constraints on farm household welfare in rural China: Evidence from Fujian Province", Sustainability, Vol. 11 No. 11, 3221, doi: $10.3390 /$ su11113221

Linh, T.N., Long, H.T., Chi, L.V., Tam, L.T. and Lebailly, P. (2019), "Access to rural credit markets in developing countries, the case of Vietnam: A literature review", Sustainability, Vol. 11 No. 5, 1468, doi: $10.3390 /$ su11051468.

Moahid, M. and Maharjan, K.L. (2020), "Factors affecting farmers' access to formal and informal credit: Evidence from rural Afghanistan", Sustainability, Vol. 12 No. 3, 1268, doi:

$10.3390 /$ su12031268.

Mpuga, P. (2010), "Constraints in access to and demand for rural credit: Evidence from Uganda", African Development Review, vol. 22 No. 1, pp. 115-148, doi: 10.1111/j.1467-8268.2009.00230.x.

Nissanke, M. and Aryeetey, E. (1998), Financial Integration and Development: Liberalization and Reform in Sub-Saharan Africa. London and New York: Routledge.

Pham, B.D. and Izumida, Y. (2002), "Rural development finance in Vietnam: a microeconometric analysis of household surveys", World Development, Vol. 30 No. 2, pp. 319-335, doi: 10.1016/S0305-750X(01)00112-7.

Ramful, P. and Zhao, X. (2008), "Individual heterogeneity in alcohol consumption: The case of beer, wine and spirits in Australia", Economic Record, Vol. 84 No. 265, pp. 207-222, doi: 10.1111/j.1475-4932.2008.00463.x.

Reyes, D.A. (2011), "Credit constraints in rural financial markets in Chile: determinants and consequences" (Doctoral dissertation, Wageningen University, Wageningen, NL)", available at: http://edepot.wur.nl/182837 (accessed 20 October 2020)

Rizwan, M., Ping, Q., Iram, S., Nazir, A. and Wang, Q. (2019), "Why and for What? An Evidence of Agriculture Credit Demand Among Rice Farmers in Pakistan", working Paper, Asian Development Bank Institute, Tokyo.

Saint-Macary, C., and Zeller, M. (2012), "Rural credit policy in the mountains of Northern Vietnam: sustainability, outreach and impact", paper presented at the Sustainable Land Use and Rural Development in Mountain Areas Conference, 16-18 April, Stuttgart, Germany.

Sanchez-Famoso, V., Maseda, A. and Iturralde, T. (2013), "Relationship between family and nonfamily social capital: The case of Spanish family firms", Revista Europea de Dirección y Economía de la Empresa, Vol. 22 No. 4, pp. 177-185, doi: 10.1016/j.redee.2013.09.001. 
Svotwa, E., Munyoro, G. and Govere, I. (2020), "The determinants of credit demand among farmers in Hurungwe District of Mashonal and West Province in Zimbabwe", Journal of Economics and International Finance, Vol. 12 No. 2, pp. 74-83, doi: 10.5897/JEIF2020.1033.

Thu, N.H., Duong, P.B. and Tho, N.H. (2020), "Filling the voids left by the formal sector: informal borrowings by poor households in northern mountainous Vietnam", Agricultural Finance Review, Vol. ahead-of-print doi: 10.1108/AFR-12-2019-0134.

Tra, P.T.T. and Lensink, R. (2008), "Household borrowing in Vietnam: A comparative study of default risks of formal, informal and semi-formal credit", Journal of Emerging Market Finance, Vol. 7 No. 3, pp. 237-261, doi: 10.1177/097265270800700302.

Train, K.E. (2009), Discrete Choice Methods with Simulation. New York, NY: Cambridge University Press.

Tran, M.C. (2014), "Credit Constraints and Impact on Rural Farm Household Welfare: The Case of Vietnam's North Central Coast region" (Master thesis, Lincoln University, Lincoln, New Zealand), available at: https://researcharchive.lincoln.ac.nz/handle/10182/6420 (accessed 20 October 2020)

Tran, M.C., Gan, C. and Hu, B. (2016), "Credit constraints and their impact on farm household welfare", International Journal of Social Economics, Vol. 43 No. 8, pp. 782-803, doi: 10.1108/ijse11-2014-0243.

Triguero, A., Moreno-Mondéjar, L. and Davia, M.A. (2013), "Drivers of different types of ecoinnovation in European SMEs", Ecological Economics, Vol. 92, pp. 25-33, doi: 10.1016/j.ecolecon.2013.04.009.

Triguero, A., Moreno-Mondéjar, L. and Davia, M.A. (2014), "The influence of energy prices on adoption of clean technologies and recycling: Evidence from European SMEs", Energy Economics, Vol. 46, pp. 246-257, doi: 10.1016/j.eneco.2014.09.020.

Truong, T.H.L., Le, T.N.Q. and Phan, H.M. (2020), "Formal versus informal credit: Which is better in helping rural areas in Vietnam?" The Journal of Asian Finance, Economics, and Business, Vol. 7 No. 5, pp. 119-130.

World Bank (2019), Vietnam Agriculture Finance Diagnostic Report: Financial Inclusion Support Framework - Vietnam Country Support Program, Washington, DC: World Bank. 
Zeller, M. (1994), "Determinants of credit rationing: a study of informal lenders and formal credit groups in Madagascar", World Development, Vol. 22 No. 12, pp. 1895-1907, doi: 10.1016/0305750x(94)90181-3. 
Table 1: Definitions of the model variables

\begin{tabular}{|c|c|c|}
\hline 1 & Variables & Explanations \\
\hline \multirow{3}{*}{$\begin{array}{l}\text { Type of credit } \\
\text { demand }\end{array}$} & $D C_{1}$ & 1 if household has formal credit demand, 0 otherwise \\
\hline & $D C_{2}$ & 1 if household has semi-formal credit demand, 0 otherwise \\
\hline & $D C_{3}$ & 1 if household has informal credit demand, 0 otherwise \\
\hline \multirow{7}{*}{$\begin{array}{l}\text { Household's } \\
\text { characteristics }\end{array}$} & Familysize & Number of people in household \\
\hline & Houseval & 1 if house value $>300$ million VND, 0 otherwise \\
\hline & Durableval & 1 if durable properties' value $>50$ million VND, 0 otherwise \\
\hline & Farmlandsize & Farmland size $\left(\mathrm{m}^{2}\right)$ \\
\hline & Socstatus & 1 if the head holds any position in community, 0 otherwise \\
\hline & Socecogroup & Number of socio-economic groups the head joins \\
\hline & Mainagrincome & 1 if primary farm production is livestock, 0 otherwise \\
\hline \multirow{4}{*}{$\begin{array}{c}\text { Household } \\
\text { head's } \\
\text { characteristics }\end{array}$} & Hgender & 1 if the head is man, 0 otherwise \\
\hline & Hage & 1 if the head is more than 45 years old, 0 otherwise \\
\hline & Hedu & 1 if the head has high school or upper education, 0 otherwise \\
\hline & Farmexpe & Years of the head's farming experience \\
\hline \multirow[t]{3}{*}{ Credit history } & Badhisfor & $\begin{array}{l}1 \text { if the household could not repay loans or had formal loans } \\
\text { restructured in past } 3 \text { years, } 0 \text { otherwise }\end{array}$ \\
\hline & Badhissemi & $\begin{array}{l}1 \text { if the household could not repay loans or had semi-formal loans } \\
\text { restructured in past } 3 \text { years, } 0 \text { otherwise }\end{array}$ \\
\hline & Badhisinfor & $\begin{array}{l}1 \text { if the household could not repay loans or had informal loans } \\
\text { restructured in past } 3 \text { years, } 0 \text { otherwise }\end{array}$ \\
\hline \multirow{4}{*}{$\begin{array}{l}\text { Geographical } \\
\text { factors }\end{array}$} & Fortime & Length of time to the closest formal credit provider (minutes) \\
\hline & Semitime & Length of time to the closest semi-formal credit provider (minutes) \\
\hline & HAN & 1 if farm locates in Ha Noi, 0 otherwise \\
\hline & HAID & 1 if farm locates in Hai Duong, 0 otherwise \\
\hline
\end{tabular}


Table 2: Farm households' credit demand in different credit markets

\begin{tabular}{ccccc}
\hline $\begin{array}{c}\text { Formal credit } \\
\text { demand }\end{array}$ & $\begin{array}{c}\text { Semi-formal credit } \\
\text { demand }\end{array}$ & $\begin{array}{c}\text { Informal credit } \\
\text { demand }\end{array}$ & Observations & Percentage \\
\hline- & - & - & 305 & $47.07 \%$ \\
Yes & - & - & 174 & $26.85 \%$ \\
- & Yes & - & 48 & $7.41 \%$ \\
- & - & Yes & 9 & $1.39 \%$ \\
Yes & Yes & - & 27 & $4.17 \%$ \\
Yes & - & Yes & 59 & $9.10 \%$ \\
- & Yes & Yes & 3 & $0.46 \%$ \\
Yes & Yes & Yes & 23 & $3.55 \%$ \\
\hline
\end{tabular}


Table 3: Descriptive statistics of the model explanatory variables

\begin{tabular}{|c|c|c|c|c|c|}
\hline & Variable & $\begin{array}{l}\text { All respondents } \\
(\mathrm{N}=648)\end{array}$ & $\begin{array}{l}\text { Formal credit } \\
\text { demand } \\
(\mathrm{N}=283)\end{array}$ & $\begin{array}{l}\text { Semi-formal } \\
\text { credit demand } \\
(\mathrm{N}=101)\end{array}$ & $\begin{array}{l}\text { Informal credit } \\
\text { demand } \\
(\mathrm{N}=94)\end{array}$ \\
\hline & & Mean (SD) & Mean (SD) & Mean (SD) & Mean (SD) \\
\hline \multirow{6}{*}{$\begin{array}{c}\text { Household's } \\
\text { characteristics }\end{array}$} & Familysize & $4.69(1.3)$ & $4.72(1.19)$ & $4.62(1.09)$ & $4.66(1.18)$ \\
\hline & Houseval & $0.76(0.43)$ & $0.71(0.46)$ & $0.56(0.5)$ & $0.59(0.5)$ \\
\hline & Durableval & $0.48(0.5)$ & $0.44(0.5)$ & $0.32(0.47)$ & $0.32(0.47)$ \\
\hline & Farmlandsize & $\begin{array}{c}4050.21 \\
(4658.89) \\
0.1(0.3)\end{array}$ & $\begin{array}{c}5124.52 \\
(5542.76) \\
0.13(0.34)\end{array}$ & $\begin{array}{c}3638.48 \\
(4585.18) \\
0.08(0.27)\end{array}$ & $\begin{array}{c}3776.18 \\
(4582.6) \\
0.05(0.23)\end{array}$ \\
\hline & Socecogroup & $1.21(1.05)$ & 1.19 (1.01) & $0.99(0.84)$ & $0.95(0.88)$ \\
\hline & Mainagrincome & $0.47(0.5)$ & $0.47(0.5)$ & $0.48(0.5)$ & $0.38(0.49)$ \\
\hline \multirow{4}{*}{$\begin{array}{l}\text { Household } \\
\text { head's } \\
\text { characteristics }\end{array}$} & Hgender & $0.7(0.46)$ & $0.75(0.43)$ & $0.6(0.49)$ & $0.72(0.45)$ \\
\hline & Hage & 0.39 (0.49) & $0.4(0.49)$ & $0.42(0.5)$ & $0.44(0.5)$ \\
\hline & Hedu & $0.58(0.49)$ & $0.58(0.49)$ & $0.42(0.5)$ & $0.5(0.5)$ \\
\hline & Farmexpe & $15.23(8.7)$ & 14.9 (8.49) & $12.34(6.98)$ & $12.37(7.65)$ \\
\hline \multirow[t]{3}{*}{ Credit history } & Badhisfor & $0.08(0.27)$ & $0.13(0.33)$ & $0.1(0.3)$ & $0.19(0.4)$ \\
\hline & Badhissemi & $0.03(0.17)$ & $0.04(0.19)$ & $0.11(0.31)$ & $0.05(0.23)$ \\
\hline & Badhisinfor & $0.02(0.13)$ & $0.02(0.13)$ & $0.02(0.14)$ & $0.07(0.26)$ \\
\hline \multirow{5}{*}{$\begin{array}{l}\text { Geographical } \\
\text { factors }\end{array}$} & Fortime & $20.06(11.22)$ & $20.73(11.55)$ & 20.89 (10.15) & $21.28(11.9)$ \\
\hline & Semitime & $17.41(10.45)$ & 18.78 (10.79) & 18.9 (12.02) & $21.78(12.91)$ \\
\hline & HAN & $0.33(0.47)$ & $0.32(0.47)$ & $0.27(0.44)$ & $0.31(0.46)$ \\
\hline & HAID & $0.33(0.47)$ & $0.27(0.45)$ & $0.25(0.43)$ & $0.36(0.48)$ \\
\hline & $\begin{array}{l}\text { Ha Nam (base } \\
\text { group) }\end{array}$ & $0.34(0.47)$ & $0.41(0.49)$ & $0.49(0.5)$ & $0.33(0.47)$ \\
\hline
\end{tabular}


Table 4: Pairwise correlation coefficient between the household's different credit demand

\begin{tabular}{lc}
\hline Pairwise correlation & Coefficient \\
\hline$\rho_{12}$ & $0.078(0.084)$ \\
$\rho_{13}$ & $0.7^{* * *}(0.057)$ \\
$\rho_{23}$ & $0.212^{* *}(0.092)$
\end{tabular}

Notes: ${ }^{* *} p<0.05 ; * * * p<0.01 ;$ standard errors are in parentheses. 
Table 5: Trivariate probit model results (marginal effects) - Determinants of credit demand

\begin{tabular}{|c|c|c|c|c|}
\hline & & $\begin{array}{l}\text { Formal credit demand } \\
\qquad\left(\mathrm{DC}_{1}\right)\end{array}$ & $\begin{array}{l}\text { Semi-formal credit } \\
\text { demand }\left(D C_{2}\right)\end{array}$ & $\begin{array}{l}\text { Informal credit demand } \\
\qquad\left(\mathrm{DC}_{3}\right)\end{array}$ \\
\hline \multirow{7}{*}{$\begin{array}{c}\text { Household's } \\
\text { characteristics }\end{array}$} & Familysize & $0.004(0.015)$ & $0.007(0.011)$ & $-0.004(0.011)$ \\
\hline & Houseval & $-0.089 *(0.045)$ & $-0.087^{* * *}(0.03)$ & $-0.067 * *(0.03)$ \\
\hline & Durableval & $-0.062(0.039)$ & $-0.062 * *(0.029)$ & $-0.05^{*}(0.028)$ \\
\hline & Farmlandsize & $0.00002^{* * *}(0.000004)$ & $-0.0000002(0.000003)$ & $0.000003(0.000003)$ \\
\hline & Socstatus & $0.072(0.062)$ & $0.018(0.048)$ & $-0.048(0.05)$ \\
\hline & Socecogroup & $-0.02(0.019)$ & $-0.02(0.015)$ & $-0.021(0.014)$ \\
\hline & Mainagrincome & $0.004(0.039)$ & $0.021(0.028)$ & $-0.039(0.027)$ \\
\hline \multirow{4}{*}{$\begin{array}{c}\text { Household } \\
\text { head's } \\
\text { characteristics }\end{array}$} & Hgender & $0.088 * *(0.041)$ & $-0.056 *(0.028)$ & $0.009(0.029)$ \\
\hline & Hage & $0.04(0.044)$ & $0.054 *(0.031)$ & $0.071 * *(0.03)$ \\
\hline & Hedu & $0.062(0.041)$ & $-0.049(0.03)$ & $0.016(0.03)$ \\
\hline & Farmexp & $-0.001(0.003)$ & $-0.006 * * *(0.002)$ & $-0.004 * *(0.002)$ \\
\hline \multirow[t]{3}{*}{ Credit history } & Badhisfor & $0.281^{* * *}(0.071)$ & $-0.06(0.053)$ & $0.065(0.045)$ \\
\hline & Badhissemi & $0.031(0.108)$ & $0.197^{* * *}(0.062)$ & $0.029(0.068)$ \\
\hline & Badhisinfor & $-0.107(0.147)$ & $-0.029(0.096)$ & $0.215^{* *}(0.087)$ \\
\hline \multirow{4}{*}{$\begin{array}{l}\text { Geographical } \\
\text { factors }\end{array}$} & Fortime & $-0.001(0.002)$ & $-0.002(0.001)$ & $-0.002(0.001)$ \\
\hline & Semitime & $0.005^{* *}(0.002)$ & $0.001(0.001)$ & $0.005^{* * *}(0.001)$ \\
\hline & $H A N$ & $-0.06(0.047)$ & $-0.039(0.034)$ & $0.008(0.033)$ \\
\hline & $H A I D$ & $-0.139 * * *(0.046)$ & $-0.062 *(0.034)$ & $0.004(0.032)$ \\
\hline \multicolumn{3}{|l|}{ Log likelihood } & -838.0183 & \\
\hline \multicolumn{3}{|l|}{ LR chi²(54) } & $185.56^{* * *}$ & \\
\hline \multicolumn{3}{|c|}{ Test of $\rho_{12}=\rho_{13}=\rho_{23}=0\left(\operatorname{chi}^{2}(3)\right)$} & $86.7557^{* * *}$ & \\
\hline \multicolumn{3}{|l|}{ Number of obs. } & 648 & \\
\hline
\end{tabular}

